\title{
Isolation and Molecular Characterization of Bacterial Strains with Antifungal Activity from Termite Mound Soil
}

\author{
Rajni Devi*, Richa Thakur and M.K. Gupta \\ Department of Microbiology, College of Basic Sciences and Humanities, CSKHPKV, \\ Palampur, Himachal Pradesh-176062, India \\ *Corresponding author
}

\section{A B S T R A C T}

\begin{tabular}{|l|}
\hline Ke y w o r d s \\
Termite mound soil, \\
Fungal pathogens, \\
Antibacterial \\
activity
\end{tabular}

\section{Introduction}

Termites process high quantities of material in their mound building activity, thus influencing the soil properties as compared to the surrounding soil (Wood, 1998). Soil of termite mounds exhibits a higher proportion of fine particles, which they transport from the deeper to upper soil horizons. In some countries, termite mound soil has been used to enrich the crop field with available nitrogen, total phosphorous and an organic carbon than the adjacent soil (Breuning et al., 2005).

Although, usually considered as pests, termites can be valuable not only in forest

\begin{abstract}
We looked for bacterial strains with antifungal activity in the termite mound soil. We have detected good antifungal activity of bacterial strains which were selected on the basis of prescreening procedure to search for plant growth promoting traits. Twenty one bacterial isolates were tested against the pathogens Sclerotium rolfsii, Alternaria sp., Colletotrichum truncatum, Rhizoctonia solani and Fusarium oxysporum. Only 10 out of 21 tested bacterial isolates showed antifungal activity against Fusarium oxysporum, 8 showed against Alternaria brassicae and Rhizoctonia solani, only one isolate showed against Sclerotium rolfsii. While, all the 21 tested bacterial isolates showed activity against Colletotrichum truncatum. Four efficient isolates named as NTS 65, BTS 14, BTS 16 and NTS 20 were further screened on the basis of 16S rRNA typing and these were identified as Staphylococcus saprophyticus, Bacillus methylotrophicus and Bacillus sp. The sequences of these isolates were submitted with NCBI gene bank.
\end{abstract}

ecosystem but also in organic farming (Arnold et al., 2017). They are great decomposers of wood and plant debris, they aerate the soil and add nutrients to it. Plants also take up nutrients very easily from termite mound soil. Termite soil is providing a viable option to local farmers who can't afford to buy expensive inorganic fertilizers.

It has been reported that bacterial and microbial populations in termitaria soil are higher than the adjacent soil (Spain 2004) and some of them have been associated with the suppression of fungal diseases. Termite mound have been used in organic farming to control some diseases, and also as a source 
with potential to enhance crop production and manage plant pathogens (Rupela, 2003).

Plant pathogens are major and chronic threat to food production and ecosystem stability worldwide. Over the past few decades, producers became more and more dependent on synthetic agro-chemicals for crop protection.

However, increased and indiscriminate use of synthetic agro-chemicals cased several negative impacts on environment and human health. Use of microbial inoculants is one of the most acceptable and eco-friendly approach to solve the problem of plant pathogens. Antagonistic activity of bacterial strains has been recognized as major factor in the suppression of many phytopathogens (David et al., 2015).

Thus the present study entitled was undertaken to demonstrate the role of termite mound soil.

In this study we searched for bacterial species with antifungal activity in the termite mound soil. We have detected good antifungal activity of bacterial strains which were selected on the basis of prescreening procedure to search for plant growth promoting traits.

Twenty one bacterial isolates were tested against the pathogens Sclerotium rolfsii, Alternaria sp., Colletotrichum truncatum, Rhizoctonia solani, and Fusarium oxysporum. Four efficient isolates named as NTS 65, BTS 14, BTS 16 and NTS 20 were further screened on the basis of $16 \mathrm{~S}$ rRNA typing and these were identified. The $16 \mathrm{~S}$ ribosomal gene sequence from the isolates NTS 65, BTS 14, BTS 16 and NTS 20 were amplified with polymerase chain reaction (PCR) and sequenced, showing identity with the as Staphylococcus saprophyticus, Bacillus methylotrophicus and Bacillus sp.

\section{Materials and Methods}

\section{Experiment site}

The present study was conducted in the Department of Microbiology, CSK HPKV, Palampur.

\section{Sample collection and bacterial isolation}

Samples for present study were collected from different regions of Himachal Pradesh as well as from Model Organic Farm, Department of Organic Agriculture, CSK HPKV, Palampur. Termite mound soil samples were collected in sterilized polythene bags from different district of Himachal Pradesh. These samples were brought to the laboratory and processed immediately or kept at refrigerator conditions for further analysis. Soil sample weighing $1 \mathrm{~g}$ was taken and transferred to $9 \mathrm{~mL}$ sterilized dilution blank under aseptic conditions and then agitated for 15 minutes on a shaker which provided $10^{-1}$ dilution and further serial dilutions were made from this accordingly. Microbial load was determined by using standard plate count technique (Wollun, 1982) by employing different media like of nutrient agar, Jensen's Agar and Pikoskaya's agar etc.

\section{Evaluation of antagonism against plant fungi}

In order to test the antifungal activity of isolates, a loop full of 48 hours old culture of each isolate was streaked at 4 sides, a little below at the centre of PDA plates, and incubated for overnight at $28 \pm 2{ }^{\circ} \mathrm{C}$, to check for contamination. Mycelia disk of 4 days old culture of each test fungal pathogen was placed simultaneously in between the streaks ( $2 \mathrm{~mm}$ apart from fungal disk). A control inoculated with test pathogen only was kept for comparison. The plates were incubated at $28 \pm 2^{\circ} \mathrm{C}$ and percent growth inhibition was calculated according to Vincent (1947). 
Percent inhibition $=\mathrm{C}-\mathrm{T} / \mathrm{C}$

Where,

$\mathrm{C}=$ radius of fungus in control $(\mathrm{mm})$

$\mathrm{T}=$ radius of fungus in treatment $(\mathrm{mm})$

\section{Characterization and identification of selected bacterial isolates}

Bacterial isolates were identified on the basis of morphological (type, shape, staining, colony characteristics) and biochemical characteristics (Oxidase, Catalase, Utilization of Sugar, Indole, MR-VP, Citrate, Urease, etc.) according to the standard method descrived in Bergey's Manual of Systematic Bacteriology (Krieg and Holf, 1984) and laboratory manual of Basic Microbiology (Kanwar et al., 1997)

\section{Molecular characterization of efficient bacterial isolates}

Molecular characterization of efficient isolates was done by $16 \mathrm{~S}$ rRNA gene sequencing method, and these sequences were blasted by using online NCBI Blast Program. http://www.ncbi.nih.gov/blast. Dendrogram was prepared by using Mega 4.1 software.

\section{Maintenance of isolates}

\section{Soft agar}

All the isolates were stocked in soft agar ( $0.5 \%$ agar) as well as on plates and slants of nutrient agar and potato dextrose agar. After the growth of isolates in incubator at $28 \pm 2{ }^{\circ} \mathrm{C}$, plates and tubes were preserved at $4^{\circ} \mathrm{C}$ under refrigerated conditions.

\section{Glycerol stocks}

Glycerol stock cultures of all the isolated microorganisms were prepared and stored at - $20^{\circ} \mathrm{C}$. Cultures were grown in $50 \mathrm{~mL}$ nutrient broth for 12 hours and $0.8 \mathrm{~mL}$ aliquots were added to $0.2 \mathrm{~mL}$ sterile $75 \%$ Glycerol in $2 \mathrm{~mL}$ vials.

\section{Results and Discussion}

\section{Antifungal activities of isolated bacteria species}

Antifungal activity of all bacterial isolates from termite mound soil was checked by Agar streaked method. Among these isolates, 21 isolates showed antagonistic activity against phytopathogen Colletotrichum truncatum, 10 against Fusarium oxysporum, 8 against Rhizoctonia solani and Alternaria brassicae and one against Sclerotium rolfsii (Table 1, Fig. 2 and 3).

In case of antifungal activity against Colletotrichum truncatum, the maximum percent inhibition was showed by BTS 16 $(59.52 \%)$ followed by NTS $65(58.73 \%)$, BTS $14(55.55 \%)$ and NTS 20 (50.00\%). The maximum antifungal activity against Fusarium oxysporum was given by BTS 14 $(67.44 \%)$ followed by NTS $65(66.67 \%)$, BTS $16(65.89 \%)$, PTS $22(62.79 \%)$ and PTS 39 (61.24\%). In case of Rhizoctonia solani, the maximum inhibition was given by BTS 16 (63.49\%), BTS 14 and PTS $39(60.31 \%)$ followed by NTS 65 (58.73\%).

Whereas, in case of Alternaria brassicae the maximum antifungal activity in terms of percent inhibition was given by NTS 20 (65\%), NTS 65 (63.33\%), BTS 14 (61.66\%) and PTS $4(60.83 \%)$.

NTS 20, NTS 65, BTS 14 and BTS 16 have found to be efficient isolates in terms of antifungal activity against selected phytopathogens and thus these can further be exploited as biocontrol agents in organic farming (Ramesh et al., 2010). 
Table.1 Antifungal activity of bacterial isolates against phytopathogens

\begin{tabular}{|c|c|c|c|}
\hline \multirow[t]{2}{*}{ Isolates } & Radius (mm) & Radius (control) & $\%$ inhibition \\
\hline & \multicolumn{3}{|c|}{ Colletotrichum truncatum } \\
\hline NTS 65 & 17.30 & 42 & 58.73 \\
\hline NTS 20 & 21.00 & 42 & 50.00 \\
\hline BTS 14 & 18.67 & 42 & 55.55 \\
\hline BTS 16 & 17.00 & 42 & 59.52 \\
\hline \multicolumn{4}{|c|}{ Fusarium oxysporum } \\
\hline NTS 65 & 14.33 & 43 & 66.67 \\
\hline NTS 20 & 18.00 & 43 & 58.14 \\
\hline PTS 22 & 16.00 & 43 & 62.79 \\
\hline BTS 14 & 14.00 & 43 & 67.44 \\
\hline BTS 16 & 14.67 & 43 & 65.89 \\
\hline PTS 39 & 16.67 & 43 & 61.24 \\
\hline \multicolumn{4}{|c|}{ Rhizoctonia solani } \\
\hline BTS 16 & 15.33 & 42 & 63.49 \\
\hline$\overline{\text { BTS } 14}$ & 16.67 & 42 & 60.31 \\
\hline PTS 39 & 16.67 & 42 & 60.31 \\
\hline NTS 20 & 19.33 & 42 & 53.97 \\
\hline NTS 65 & 17.33 & 42 & 58.73 \\
\hline \multicolumn{4}{|c|}{ Alternaria brassicae } \\
\hline$\overline{\text { BTS } 16}$ & 19.00 & 40 & 52.50 \\
\hline BTS 14 & 15.33 & 40 & 61.66 \\
\hline NTS 65 & 14.67 & 40 & 63.33 \\
\hline NTS 20 & 14.00 & 40 & 65.00 \\
\hline \multicolumn{4}{|c|}{ Sclerotium rolfsii } \\
\hline PTS 22 & 17.00 & 43 & 60.47 \\
\hline
\end{tabular}

Fig.1 Phylogenetic tree of molecularly characterized isolates

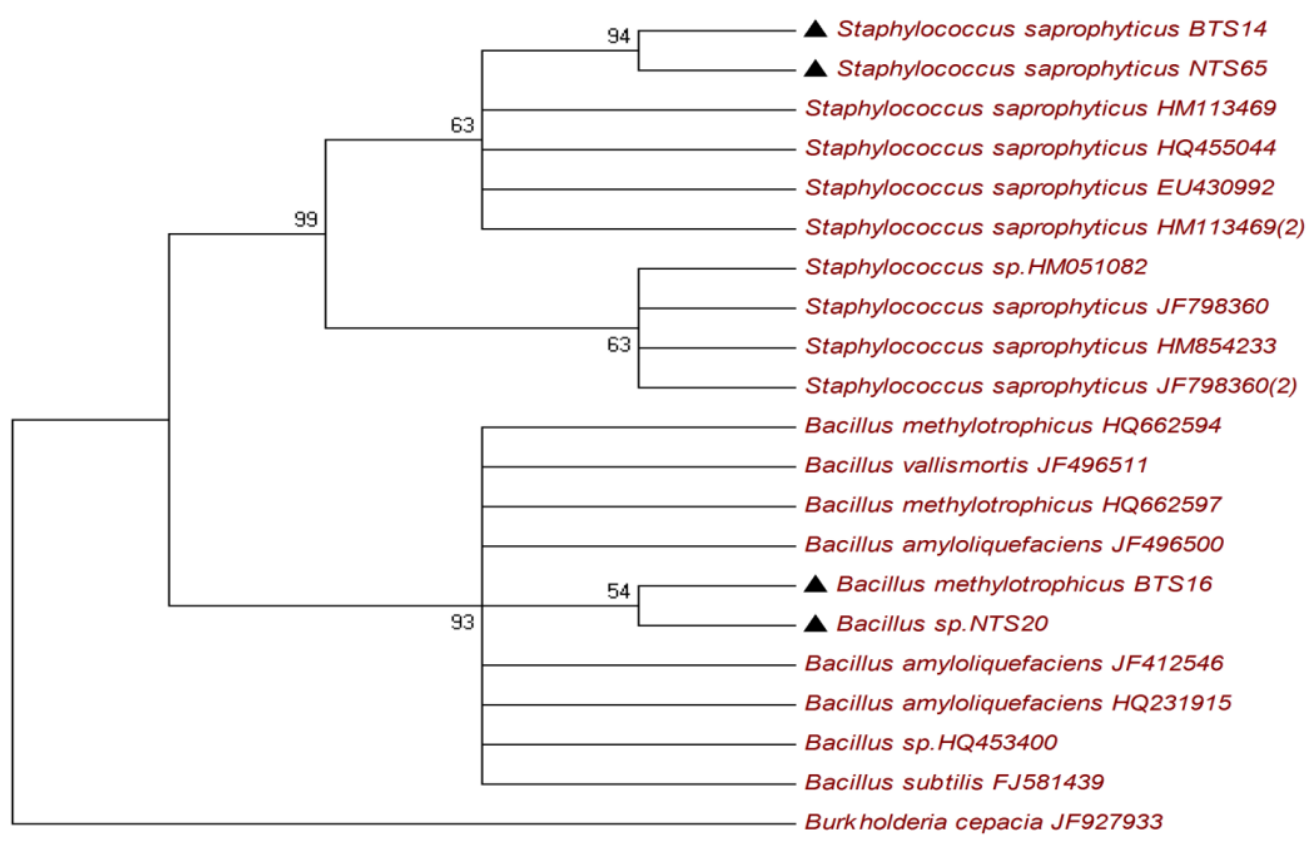


Fig.2 Antifungal activity of bacterial isolates against Colletotrichum truncatum (a) and Fusarium oxysporum (b) bacterial isolates showing inhibition against Colletotrichum truncatum (c-d) and Fusarium oxysporum (e-f)

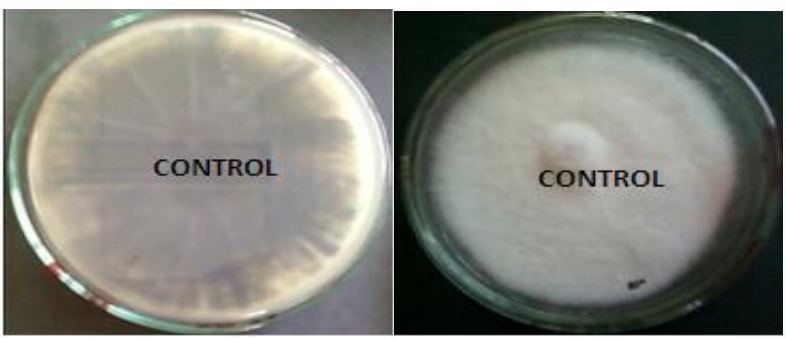

(a)

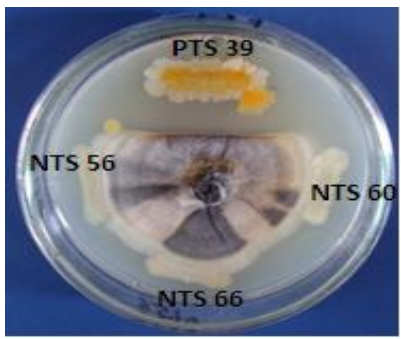

(d) (b)

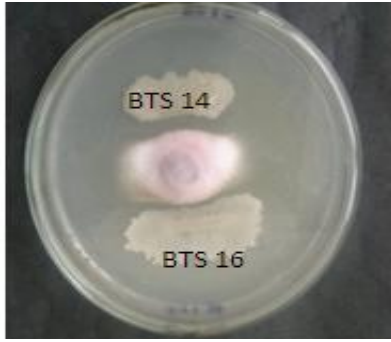

(e)

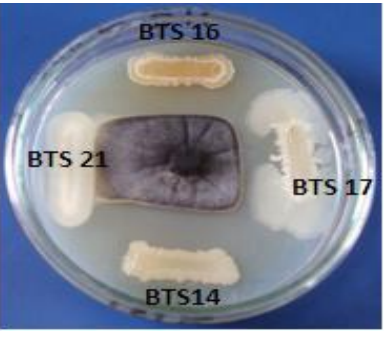

(c)

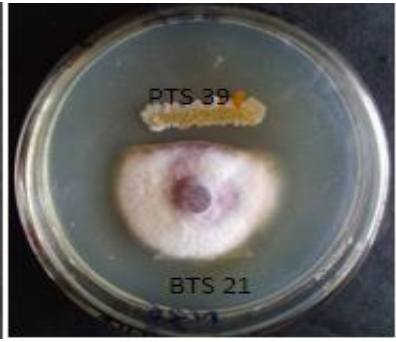

(f)

Fig.3 Antifungal activity of bacterial isolates against Alternaria brassicae (a) Rhizoctonia solani (b) Sclerotium rolfsii (e) bacterial isolates showing inhibition against Alternaria sp. (c) Rhizoctonia solani (d) and Sclerotium rolfsii (f)

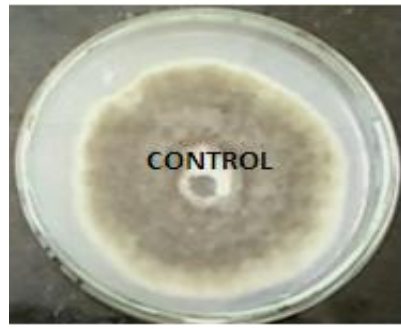

(a)

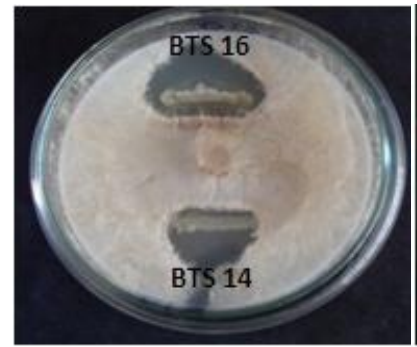

(d)

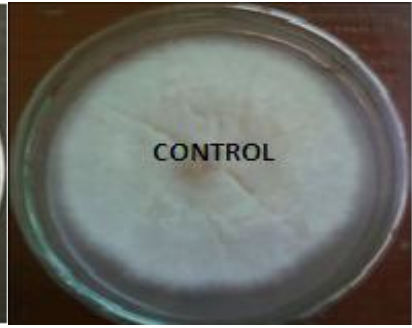

(b)

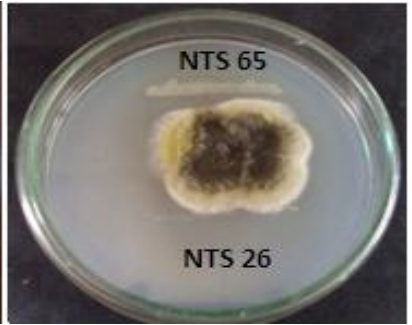

(c)

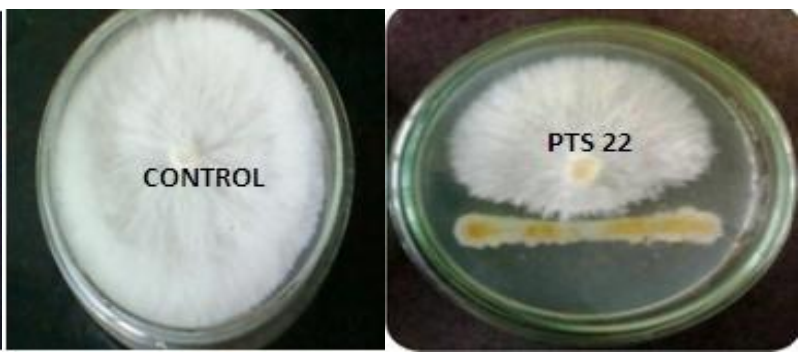

(e)

(f) 
Exhibition of antifungal activity could be attributed to production of substances like siderophore, HCN, organic acid etc. and these observations are in correspondence with the study of Srivastava et al., (2004) and Bano et al., (2004).

\section{Molecular characterization of efficient bacterial isolates}

Those bacterial isolates which showed maximum biological activities were further characterized on the basis of molecular characteristics. After 16s rRNA gene sequencing, the sequences obtained were submitted to NCBI GeneBank Nucleotide Database.

Analysis of the sequences, using BLASTN algorithm of NCBI, identified the isolates were found to be belonging to two bacterial species. On the basis of high sequence similarity shown to a particular bacterial species already available in the GeneBank. Isolate NTS 65 and BTS 14 have shown sequence similarity with Staphylococcus saprophyticus strain (JF 798360, HQ 455044, EU 430992 and HM 113469). Whereas, BTS 16 have shown sequence similarity to Bacillus methylotrophicus (HQ 662597, HQ 662594). And NTS 20 have shown sequence similarity with Bacillus species (HQ 453400) as shown in dendrogram. NCBI gene Bank allotted Accession number to two molecularly characterized cultures, NTS 65 (JN 162677) and BTS 14 (JN 162676).

The phylogenetic tree prepared with $16 \mathrm{~S}$ rRNA gene sequence of Burkholderia capacia as an outgroup bacterium and 16 other gene sequences of bacteria selected from NCBI, these 4 isolates under study were found to belonging to three groups. Group I was identified as $B$. methylotrophicus, group II as Bacillus species and group III identified as staphylococcus saprophyticus.
Many workers have identified bacterial strains belonging to genus Bacillus and Staphylococcus associated with the soils by using specific primer sets and $16 \mathrm{~S}$ rRNA gene analysis coupled with conventional identification techniques (Pamela et al., 2010).

\section{References}

Arnold, V H., 2017.Cultural significance of termites in sub-Saharan Africa. Journal of Ethnobiology and Ethnomedicine $13: 8$

Bano, N., and Musarrat, J. 2004. Characterization of a novel carbofuran degrading Pseudomonas sp. with collateral biocontrol and plant growth promoting potential. FEMS Microbiology Letters 231(1):13-17

Breuning- Madsen, H., Awadzi T W., and Mount, H R. 2005. The classification of soils modified by Termite Activity in the Tropical Moist semi-decidous Forests of West Africa. Soil Survey Horizon. 45(3): 4

David, M., O and Samuel, O W. 2015. Antimicrobial Activities of Microorganisms Obtained from the gut of Macrotermes michaelseni in Maseno, Kenya. Journal of Applied Biology and Biotechnology 3 (06): 48-52

Kanwar, S S., Gupta, M K. and Punj, V. 1997. Biochemical reaction and their significance. In: Laboratory Manual of Basic Microbiology 5:54-64

Krieg, N R., and Holt, J G. 1984. Bergey's Manual of Determinative Bacteriology $9^{\text {th }}$ Edition.

Latha P and Natarajan C 2010. Importance of biological control in agriculture. Agrobios Newsletter 9(1): 38-39

Pamela, C., Ernesto, O O., Esperanza, M R., and Doris, Z.2010. Characterization of bacillus isolates of potato rhizosphere from andean soils of Peru and their 
potential PGPR characteristics. Brazilian Journal of Microbiology 41: 899-06

Parvathi, A., Krishna, K., Jose, J., Joseph, N., and Nair, S. 2009. Biochemical and molecular characterization of Bacillus pumilus isolated from coastal environment in Cochin, India. Brazilian Journal of Microbiology 40(1): 269-75

Ramesh, P., Panwar, N R., Singh, A B., Ramana, R., Yadav, S K., Shrivaastava, R., and Rao, A S. 2010. Status of organic farming in India. Current Science 98(9): 1190-94

Rupela, O., Tiwari, A., and Singh, J. 2003. Organic resources of a part of Indogangetic plain and their utilization. Soil biology $93: 34-45$
Spain, A V., Gordon, V., Paul, R and Correll, R. 2004.Ectomycorrhizal fungal spores in the mounds of tropical Australian termites. European Journal of soil biology 40(3): 9-14

Srivastva, S., Yadav, K S., and Kundu, B S. 2004. Prospects of using phosphate solubilizing Pseudomonas as biofungicide. Indian Journal of Microbiology 44(3): 91-94

Wollum, A G., 1982. Cultural methods for soil microorganisms. In: Methods of soil analysis, Part II, chemical and microbiological properties. American Society of Agronomy, Inc. Publisher Madison, Wisconsin, USA pp 781-02

Wood, T G., 1998. Termites and the soil environment. Biology of Fertile Soils 6: 228-36

\section{How to cite this article:}

Rajni Devi, Richa Thakur and Gupta, M.K. 2018. Isolation and Molecular Characterization of Bacterial Strains with Antifungal Activity from Termite Mound Soil. Int.J.Curr.Microbiol.App.Sci. 7(04): 1-7. doi: https://doi.org/10.20546/ijcmas.2018.704.001 